\title{
HUBUNGAN ANTARA PENGETAHUAN TENTANG SUMBER DAYA AIR DAN SIKAP TERHADAP PENGGUNAAN AIR DENGAN PERILAKU DALAM MEMANFAATKAN AIR (Studi Pada Masyarakat di Desa Linggasirna Kecamatan Sariwangi Kabupaten Tasikmalaya)
}

\author{
Gugum Gumilar, Yoni Hermawan \\ Program Studi Pendidikan Ekonomi Fakultas Keguruan dan Ilmu Pendidikan (FKIP) \\ Universitas Siliwangi Tasikmalaya \\ Yoni14id@yahoo,com
}

\begin{abstract}
AB S T RACT
The study concluded that: (1) there is a relationship between people's knowledge about the behavior of water resources in the use of water $r=0,415$ and $r^{2}=17,2 \%$. The higher people's knowledge about water resources, the use of positive behavior in the water anyway, (2) there is a positive relationship between attitude towards water use behavior in the use of water in the Village District Linggasirna Sariwangi Tasikmalaya district $r=0,396$ and $r^{2}=15,7 \%$. The more positive attitudes towards the use of water, the use of positive behavior in the water anyway, and (3) there is a relationship between people's knowledge about water resources and public attitudes towards water use behavior in the use of water $r=0,454$ and $r^{2}=20,6 \%$. The higher people's knowledge about water resources and increasingly positive attitude toward the use of water, the use of positive behavior in the water anyway.
\end{abstract}

Keyword : Knowledge Society on Water Resources and Water Use

\begin{abstract}
AB STRAK
Penelitian menyimpulkan bahwa : (1) ada hubungan antara pengetahuan masyarakat tentang sumber daya air dengan perilaku dalam memanfaatkan air, hal ini ditunjukan dengan $r=0,415$ dan $\mathrm{r}^{2}=17,2 \%$. Makin tinggi pengetahuan masyarakat tentang sumber daya air, makin baik pula perilakunya dalam memanfaatkan air; (2) ada hubungan positif antara sikap terhadap penggunaan air dengan perilaku dalam memanfaatkan air di Desa Linggasirna Kecamatan Sariwangi Kabupaten Tasikmalaya, hal ini ditunjukan dengan $r=0,396$ dan $r^{2}=15,7 \%$. Makin positif sikap masyarakat terhadap penggunaan air, makin baik pula perilakunya dalam memanfaatkan air; dan (3) ada hubungan antara pengetahuan masyarakat tentang sumber daya air dan sikap masyarakat terhadap penggunaan air dengan perilaku dalam memanfaatkan air, hal ini ditunjukan dengan $r=0,454$ dan $\mathrm{r}^{2}=20,6 \%$. Makin tinggi pengetahuan masyarakat tentang sumber daya air dan makin positif sikapnya terhadap penggunaan air, makin positif pula perilakunya dalam memanfaatkan air.
\end{abstract}

Kata Kunci : pengetahuan sumber daya air, sikap dan perilaku dalam memanfaatkan air 


\section{Pendahuluan}

Dewasa ini air menjadi masalah yang perlu mendapat perhatian yang seksama dan cermat. Untuk memperoleh air yang baik sesuai dengan standar tertentu, saat ini amatlah susah karena badan air sudah banyak yang tercemar oleh berbagai macam limbah hasil kegiatan manusia, baik limbah rumah tangga, limbah industri, maupun limbah-limbah lainnya. Air merupakan kebutuhan pokok bagi kehidupan manusia di bumi. Sesuai dengan kegunaannya, secara konvensional air dipakai untuk minum, mandi dan mencuci, pengairan lahan pertanian, perikanan, sanitasi, transportasi, dan sebagainya. Sedangkan untuk meningkatkan kualitas hidup manusia, air juga digunakan untuk menunjang kegiatan industri dan teknologi, seperti air proses, air pendingin, air ketel uap penggerak turbin, air utilitas, dan sanitasi.

Pengelolaan sumber daya air di Indonesia menghadapi problema yang sangat rumit dan kompleks, mengingat air mempunyai beberapa fungsi baik fungsi sosial-budaya, ekonomi dan lingkungan yang masing-masing dapat saling bertentangan. Dengan terjadinya perubahan iklim global, semakin meningkatnya jumlah penduduk dan intensitas kegiatan ekonomi, telah terjadi perubahan sumberdaya alam yang sangat cepat.

Masyarakat memperoleh air untuk kehidupannya bisa berasal dari berbagai sumber, di antaranya air tanah, sungai, kolam, air hujan, air laut, dan sebagainya. Di daerah-daerah pedesaan dimana air ledeng belum masuk, kebanyakan penduduk menggunakan air sumur untuk kebutuhan air minum, memasak, ataupun MCK. Tidak mudah mengelola air sebagai bahan utama kehidupan jika ditinjau dari berbagai sudut kepentingan. Perlu penekenan lebih terhadap bagaimana mengelola air sebagai salah satu sumber daya alam yang sangat menunjang kehidupan. Masyarakat hendaknya mempunyai rasa memiliki terhadap air. Namun tidak mudah menanamkan rasa memiliki jika tidak dimulai dari pengetahuan mereka tentang sumber daya air.

Kenyataan yang penulis temukan di Desa Linggasirna Kecamatan Sariwangi Kabupaten Tasikmalaya, banyak masyarakat menggunakan air secara berlebihan atau tidak sesuai dengan peruntukkannya, misalnya air layak minum malah digunakan untuk mengairi kolam atau sawah yang nyata-nyata kolam dan sawah-sawah tersebut telah memenuhi standar air yang seharusnya, dan masih banyak hal lain yang terkesan air tidak dihemat dalam penggunaannya.

Peristiwa tersebut bisa saja dikarenakan masyarakat beranggapan bahwa persediaan air di daerah tersebut cukup banyak, sehingga mereka terkesan acuh dalam penghematan air sebagai salah satu sumber daya, mereka tidak berpikir bahwa sumberdaya air akan habis jika tidak diikuti dengan pemeliharaan sumber-sumber air, hal ini dimungkinkan pada ketidaktahuan masyarakat di daerah itu terhadap pentingnya menghemat air dalam penggunaannya yang berdampak pada sikap serta perilaku mereka dalam memperlakukan air terkesan seenaknya tanpa memperhatikan kaidah-kaidah tertentu dalam penggunaan air.

Sekaitan dengan hal-hal tersebut di atas, menarik bagi penulis untuk melakukan sebuah penelitian ilmiah mengenai hubungan pengetahuan masyarakat tentang sumber daya air dan sikap masyarakat terhadap penggunaan air dengan perilakunya dalam memanfaatkan air sebagai salah satu sumber daya utama dalam kehidupan.

\section{Rumusan Masalah}

Permasalahan pokok yang akan dicari jawabannya melalui penelitian ini dapat dirumuskan sebagai berikut :

1. Adakah hubungan antara pengetahuan masyarakat tentang sumber daya air dengan perilaku dalam memanfaatkan air?;

2. Adakah hubungan antara sikap masyarakat terhadap penggunaan air dengan perilaku dalam memanfaatkan air ?; dan

3. Adakah hubungan antara pengetahuan masyarakat tentang sumber daya air dan sikap masyarakat terhadap penggunaan air dengan perilaku dalam memanfaatkan air.

\section{Tujuan Penelitian}

Penelitian ini bertujuan untuk mengetahui :

1. Hubungan antara pengetahuan masyarakat tentang sumber daya air dengan perilaku dalam memanfaatkan air;

2. Hubungan antara sikap masyarakat terhadap penggunaan air dengan perilaku dalam memanfaatkan air; dan 
3. Hubungan antara pengetahuan masyarakat tentang sumber daya air dan sikap masyarakat terhadap penggunaan air dengan perilaku dalam memanfaatkan air.

\section{Kajian Pustaka}

Sebagaian besar pengetahuan manusia diperoleh melalui mata dan telinga. "Pengetahuan atau kognitif merupakan domain yang sangat penting untuk terbentuknya perilaku seseorang (Notoatmodjo 2003 : 23)". Menurut Taufik (2007 : 67), "Pengetahuan merupakan penginderaan manusia, atau hasil tahu seseorang terhadap objek melalui indera yang dimilikinya (mata, hidung, telinga, dan lain sebagainya)".

Banyak pengertian mengenai sikap yang dikemukakan oleh para ahli. Mar'at (2007: 12) berpendapat bahwa "Sikap adalah kesiapan beraksi terhadap objek di lingkungan tertentu sebagai suatu penghayatan terhadap objek tersebut. Hal ini sependapat dengan Bimo Walgito (2001: 109) yang menjelaskan bahwa "Sikap merupakan suatu organisasi pendapat, keyakinan seseorang mengenai objek atau situasi yang relatif ajeg, yang disertai adanya perasaan tertentu, dan memberikan dasar kepada orang tersebut untuk membuat respon atau perilaku dalam cara yang tertentu yang dipilihnya".

Ada banyak pendapat yang berhubungan dengan hubungan stimulus dengan respons ini, di antaranya formulasi yang dikemukakan oleh Kurt Lewin dalam Bimo Walgito (1988 : 16). Lewin memberikan formulasi mengenai perilaku dengan bentuk $\mathrm{B}=\mathrm{f}(\mathrm{E}, \mathrm{O})$ denga keterangan $\mathrm{B}=$ behavior, $\mathrm{f}$ = fungsi, $\mathrm{E}=$ environment dan $\mathrm{O}=$ organisme. Formulasi tersebut memberikan pengertian bahwa perilaku (behavior) itu tergantung pada lingkungan dan organisme yang bersangkutan. Di samping formulasi tersebut ada lagi formulasi lain yaitu yang berbetuk $\mathrm{B}=\mathrm{f}(\mathrm{E}$ ? O) yaitu bahwa perilaku bergantung terhadap interaksi antara lingkungan dengan organisme dalam bentuk hubungan interaksional. Dari formulasi-formulasi di atas tampak bahwa perilaku individu tergantung pada lingkungan atau stimulus dengan organisme yang bersangkutan.

\section{METODEPENELITIAN}

\subsection{Populasi dan Sampel}

Populasi dari penelitian ini adalah semua anggota masyarakat yang di Desa Linggasirna Kecamatan Sariwangi Kabupaten Tasikmalaya. Inilah yang disebut sebagai populasi sasaran (target population). Sementara itu yang menjadi populasi terjangkau (acccesible population) dari penelitian ini adalah seluruh anggota populasi sasaran Desa Linggasirna Kecamatan Sariwangi Kabupaten Tasikmalaya yaitu seluruh kepala keluarga yang pada waktu penelitian sedang ada di tempat yang didasarkan pada tingkat pendidikan yang dikategorikan menjadi pendidikan dasar (lulus SD dan SMP sederajat), pendidikan menengah (lulus SMA sederajat) dan pendidikan tinggi (lulus D1, D2, D3, S1 dan S2).

Anggota-anggota populasi terjangkau yang terpilih sebagai responden penelitian merupakan sampel dari penelitian ini. Dengan demikian, maka kepala rumah tangga inilah yang disebut sebagai subjek penelitian.

Proses pengambilan sampel dilaksanakan dengan langkah-langkah sebagai berikut :Pertama, mendata jumlah kepala keluarga yang ada di Desa Linggasirna Kecamatan Sariwangi Kabupaten Tasikmalaya. Kedua, memilih anggota sampel berdasarkan tingkat pendidikan yang telah ditentukan dengan menggunakan teknik acak sederhana.

Berdasarkan langkah-langkah tersebut, maka besar populasi penelitian pada waktu penelitian dilaksanakan adalah 597 kepala keluarga, Dari jumlah populasi tersebut diambil jumlah sampel sebesar 60 sampel atau sekitar $10 \%$ dari populasi secara stratified proportional random sampling. Hal ini sesuai dengan pendapat Russeffendi (1994 : 92) yaitu bahwa untuk penelitian deskriptif sampel minimum adalah $10 \%$ dari populasi, sedangkan untuk populasi yang lebih kecil sebesar $20 \%$. Untuk penelitian korelasional paling sedikit jumlah subjeknya adalah 30 orang.

Metode yang digunakan dalam penelitian ini adalah deskriptif korelasional. Dipilihnya metode ini 
karena penelitian yang penulis lakukan tidak untuk menentukan sebab akibat antar variabel yang terlibat dalam penelitian, tetapi hanya mendeskripsikan secara kuantitatif hubungan antara variabel itu dalam bentuk koefisien korelasi.

\subsection{Instrumen Penelitian}

Untuk menjaring data yang diperlukan, disusun seperangkat instrumen dalam bentuk tes pengetahuan, angket sikap, dan kuesioner perilaku. Sebelum digunakan dalam penelitian, terlebih dahulu disusun instrumennya, dilakukan uji coba instrumen, analisis kesahihan dan keterandalan, dan revisi instrumen.

\section{a. Uji validitas}

Teknik yang digunakan untuk mengetahui validitas butir soal digunakan rumus

Product Moment dengan angka kasar :

Keterangan :

$\mathrm{r}_{\mathrm{xy}}=$ Koefisien korelasi antara variabel $\mathrm{X}$ dan variabel Y

$\mathrm{X}=$ Skor tiap item

$\mathrm{Y}=$ Skor tiap peserta tes

?X = Jumlah skor tiap item/butir soal yang diperoleh tiap peserta

$?$ Y = Jumlah skor seluruh peserta tes

$\mathrm{N} \quad$ Banyak subjek

Validitas setiap butir soal, ditentukan berdasarkan kriteria sebagai berikut : $<0,00=$ berkorelasi negatif (soal harus dibuang)

$0,00-0,20=$ berkorelasi sangat rendah

$0,21-0,40=$ berkorelasi rendah

$0,41-0,70=$ berkorelasi cukup

$0,70-0,90=$ berkorelasi tinggi

$0,91-1,00=$ berkorelasi sangat tinggi b. Uji reliabilitas butir soal

Untuk menguji reliabilitas butir soal digunakan rumus $\mathrm{KR}_{20}$ (Arikunto, Suharsimi 1993 : 52 ), sebagai berikut :

Keterangan :

$\mathrm{KR}_{20}=$ Koefisien Reliabilitas $\mathrm{n}=$ banyak butir soal

$\mathrm{s}^{2}=$ varians total

$\mathrm{p}=$ proporsi subjek yang menjawab benar pada suatu butir

$\mathrm{q}=$ proporsi subjek yang mendapat skor 0

Reliabilitas soal ditentukan berdasarkan kriteria sebagai berikut : $\mathrm{KR}_{20}=0,00-0,20$ maka reliabilitas rendah sekali.

$\mathrm{KR}_{20}=0,21-0,40$ maka reliabilitas rendah.

$\mathrm{KR}_{20}=0,41-0,60$ maka reliabilitas cukup.

$\mathrm{KR}_{20}=0,61-0,80$ maka reliabilitas tinggi.

$\mathrm{KR}_{20}=0,81-1,00$ maka reliabilitas tinggi sekali.

Sedangkan untuk uji reliabilitas angket dan kuisoiner digunakan rumus alpha cronbach, sebagai berikut :

Keterangan :

r11 : reliabilitas

n : banyak butir soal

2 : varians total

$\mathrm{p} \quad$ : proporsi subjek yang menjawab benar pada butir soal (prporsi subjek yang mendapat skor 1)

q : proporsi subjek yang mendapat skor nol $(q=1-p)$ 


\subsection{Teknik Analisis Data}

Data yang diperoleh dari penelitian dianalisis dengan menggunakan teknik korelasi, regresi sederhana dan regresi ganda. Selain teknik-teknik analisis tersebut, beberapa teknik analisis univariat untuk kepentingan deskripsi data juga dilakukan, yakni rata-rata (mean), median (nilai tengah), nilai terkecil dan nilai terbesar, serta simpangan baku. Sebelum teknik-teknik analisis korelasi dan regresi yang ditujukan untuk menguji hipotesis tersebut digunakan, terlebih dahulu dilakukan pengujian terhadap persyaratan-persyaratan analisis. Untuk keperluan ini maka dilakukanlah uji normalitas sebaran data, dan uji linearitas bentuk regresi dan korelasi ganda dengan menggunakan Uji F. Semua pengujian di atas dilakukan dalam taraf signifikansi atau taraf $?=0,05$.

\section{HASILDANPEMBAHASAN}

Data yang diperoleh terdiri dari skor pengetahuan tentang sumber daya air $\left(\mathrm{X}_{1}\right)$, skor sikap terhadap penggunaan air $\left(\mathrm{X}_{2}\right)$, dan skor perilaku dalam memanfaatkan air $(\mathrm{Y})$. Respoden yang menjadi subjek penelitian sebanyak 60 kepala keluarga di Desa Linggasirna Kecamatan Sariwangi Kabupaten Tasikmalaya. Setelah deskripsi data, selanjutnya disajikan pula pengujian persyaratan analisis, pengujian hipotesis dan pembahasannya.

\section{Pengetahuan tentang Sumber Daya Air}

Hasil pengolahan data dari responden sebanyak 60 kepala keluarga menunjukkan bahwa skor terendah 12 dan skor tertinggi 29 , rata-ratanya sebesar 18,15 dan simpangan bakunya sebesar 5,374 dengan varians 28,875 .

Tabel

Data Skor Variabel Pengetahuan tentang Sumber Daya Air

\begin{tabular}{|c|c|c|c|}
\hline Mean & SD & Skor Minimum & Skor Maksimum \\
\hline 18,15 & 5,374 & 12 & 29 \\
\hline
\end{tabular}

\section{Sikap terhadap Penggunaan Air}

Hasil pengolahan data dari responden sebanyak 60 kepala keluarga menunjukkan skor terendah 40 dan skor tertinggi 96 , rata-ratanya sebesar 59,48 dan simpangan bakunya sebesar 14,311 dengan varians 204,796.

Tabel

Data Skor Variabel Sikap terhadap Penggunaan Air

\begin{tabular}{|c|c|c|c|}
\hline Mean & SD & Skor Minimum & Skor Maksimum \\
\hline 59,48 & 14,311 & 40 & 96 \\
\hline
\end{tabular}

\section{Perilaku dalam Memanfaatkan Air}

Data perilaku dalam memanfaatkan air dilakukan, diolah secara uni variabel dan hasilnya diperoleh data sebagai berikut, skor terendah 45 dan skor tertinggi 89, rata-ratanya sebesar 69,40 dan simpangan bakunya sebesar 13,531 dengan varians sebesar 183,092.

Tabel

Data Skor Variabel Perilaku dalam Memanfaatkan Air

\begin{tabular}{|c|c|c|c|}
\hline Mean & SD & Skor Minimum & Skor Maksimum \\
\hline 69,40 & 13,531 & 45 & 89 \\
\hline
\end{tabular}

\section{Pengujian Persyaratan Analisis}

\section{Uji Normalitas}

Untuk menguji normalitas sebaran data digunakan Uji Normalitas Kolmogorov-Smirnov Z. Data yang diuji adalah data dari ketiga variabel dalam penelitian ini yaitu hubungan pengetahuan tenatang sumber daya air dan sikap terhadap penggunaan air dengan perilaku dalam memanfaatkan air. Berdasarkan hasil perhitungan diperoleh :

a. Untuk data variabel pengetahuan tentang sumber daya air $\left(\mathrm{X}_{1}\right)$ didapat harga signifikansi (SIG) sebesar 0,089 yang lebih besar dari harga probabilitas á $(0,05)$ maka dapat dikatakan data berasal dari populasi berdistribusi normal.

b. Untuk data variabel sikap terhadap penggunaan air $\left(\mathrm{X}_{2}\right)$ didapat harga harga signifikansi (SIG) sebesar 0,364 yang lebih besar dari harga probabilitas á $(0,05)$ maka dapat dikatakan data berasal dari populasi berdistribusi normal. 
c. Untuk data variabel perilaku dalam memanfaatkan air (Y) didapat harga signifikansi (SIG) sebesar 0,089 yang lebih besar dari harga probabilitas á $(0,05)$ maka dapat dikatakan data berasal dari populasi berdistribusi normal. terhadap penggunaan air berhubungan secara linier dengan perilaku dalam memanfaatkan air.

c. Uji linieritas regresi variabel hubungan Pengetahuan tentang sumber daya air $\left(\mathrm{X}_{1}\right)$ dan

Tabel

Hasil Pengujian Normalitas Data

\begin{tabular}{lccc}
\hline Variabel Penelitian & Signifikansi & Probabilitas & Keterangan \\
\hline $\begin{array}{l}\text { Pengetahuan tentang sumber } \\
\text { daya air }\end{array}$ & 0,089 & 0,05 & Normal \\
$\begin{array}{l}\text { Sikap terhadap penggunaan air } \\
\text { Perilaku dalam memanfaatkan air }\end{array}$ & 0,364 & 0,05 & Normal \\
& 0,089 & 0,05 & Normal
\end{tabular}

\section{Uji Linearitas Regresi}

Persyaratan kedua dalam pengujian persyaratan analisis adalah uji linieritas regresi. Dalam penelitian ini digunakan uji beda R kuadrat. Karena variabel dalam penelitian ini ada dua buah variabel bebas (pengetahuan tentang sumber daya air dan sikap terhadap penggunaan air) dan satu buah variabel terikat (perilaku dalam memanfaatkan air). Berikut ini akan disajikan hasil uji linieritas regresi dari variabelvariabel tersebut masing-masing :

a. Uji linieritas regresi variabel hubungan pengetahuan tentang sumber daya air $\left(\mathrm{X}_{1}\right)$ variabel dengan perilaku dalam memanfaatkan air (Y). Hasil perhitungan didapat $\mathrm{R}^{2}$ beda sebesar 0,172 dan harga $\mathrm{F}_{\text {hitung }}$ sebesar 12,052 sedangkan harga Asympt Sig. 0,001. Ternyata Asympt Sig lebih kecil dari taraf signifikasi ? sebesar 0,05. Maka dapat disimpulkan bahwa regresi kedua variabel tersebut linier. Ini berarti bahwa variabel pengetahuan tentang sumber daya air berhubungan dengan perilaku dalam memanfaatkan air

b. Uji linieritas regresi variabel sikap terhadap penggunaan air $\left(\mathrm{X}_{2}\right)$ dengan variabel perilaku dalam pemanfaatan air (Y). Hasil perhitungan didapat $\mathrm{R}^{2}$ beda sebesar 0,157 dan harga $\mathrm{F}_{\text {hitun }}$ sebesar 10,765 sedangkan harga Asympt Sig. sebesar 0,002. Ternyata Asympt Sig. hitung lebih kecil dari taraf signifikasi ? sebesar 0,05. Maka dapat disimpulkan bahwa regresi kedua variabel tersebut linier. Ini berarti bahwa sikap sikap terhadap penggunaan air $\left(\mathrm{X}_{2}\right)$ dengan perilaku dalam memanfaatkan air (Y). Hasil perhitungan didapat $\mathrm{R}^{2}$ beda sebesar 0,206 dan harga $\mathrm{F}_{\text {hitung }}$ sebesar 7,401 sedangkan harga Asympt Sig. sebesar 0,001. Ternyata Asympt Sig. hitung lebih kecil dari taraf signifikasi ? sebesar 0,05. Maka dapat disimpulkan bahwa regresi ketiga variabel tersebut linier. Ini berarti hubungan pengetahuan tentang sumber daya air dan sikap terhadap penggunaan air berhubungan dengan perilaku dalam memanfaatkan air.

Rangkuman hasil uji linearitas regresi terdapat dalam Tabel berikut ini.

\section{Pengujian Hipotesis}

Berikut ini akan disajikan hasil pengujian terhadap hipotesis yang diajukan pada penelitian ini.

\section{Hubungan antara Pengetahuan Masyarakat tentang Sumber Daya Air dengan Perilaku dalam MemanfaatkanAir}

Hipotesis pertama yang diajukan dalam penelitian ini adalah ada hubungan antara pengetahuan masyarakat tentang sumber daya air dengan perilaku dalam memanfaatkan air. Dari hasil analisis regresi linier sederhana terhadap data penelitian dihasilkan konstanta a sebesar 50,443 dan koefisien arah regresi b sebesar 1,044. Bentuk 
Gugum Gumilar, dkk. : Hubungan Antara Pengetahuan Tentang Sumber Daya Air .....

Rangkuman Hasil Uji Linieritas Regresi dengan Uji Beda R²

\begin{tabular}{ccccc}
\hline & \multicolumn{3}{c}{ Uji Beda R $^{2}$} & \multirow{2}{*}{ Simpulan } \\
\cline { 2 - 4 } Variabel Penelitian & Fhitung & $?$ & Asympt Sig & \\
\cline { 2 - 4 } & & 0,05 & 0,001 & Linier \\
$\mathrm{X} 1 \longrightarrow \mathrm{Y}$ & 12,052 & 0,05 & 0,002 & Linier \\
$\mathrm{X}_{2} \longrightarrow \mathrm{Y}$ & 10,765 & 0,05 & 0,001 & Linier \\
$\mathrm{X}_{1}+\mathrm{X}_{2} \longrightarrow \mathrm{Y}$ & 7,401 & & & \\
\hline
\end{tabular}

hubungan antara kedua variabel dapat disajikan oleh persamaan regresi $\mathrm{Y}=50,443+1,044 \mathrm{X}_{1}$.

Kekuatan hubungan antara hubungan pengetahuan tentang sumber daya air $\left(\mathrm{X}_{1}\right)$ dengan perilaku dalam memanfaatkan air $(\mathrm{Y})$ pada model persamaan $\mathrm{Y}=50,443+1,044 \mathrm{X}_{1}$ dapat dilihat pada koefisien determinasi $\left(\mathrm{r}^{2}\right)$ adalah 0,172 . Ini berarti hubungan pengetahuan tentang sumber daya air memberikan kontribusi sebesar $17,2 \%$ terhadap perilaku dalam memanfaatkan air, dan sisanya dipengaruhi oleh variabel lain, misalnya tingkat pendidikan masyarakat dan tingkat pendapatan masyarakat.

Analisis korelasi terhadap pasangan data dari kedua variabel tersebut menghasilkan koefisien korelasi $\mathrm{r}$ sebesar 0,415 , artinya hubungan antar kedua variabel tersebut berada dalam kategori cukup. Keberartian koefisien korelasi tersebut selanjutnya diuji dengan menggunakan uji $t$ menghasilkan $t_{\text {hitung }}$ sebesar 8,864 dan $\mathrm{t}_{\text {tabel }}$ dengan $\mathrm{db}=58$ pada taraf signifikansi $5 \%$ sebesar 4,96 . Ternyata $t_{\text {hitung }}$ lebih besar dari $t_{\text {tabel }}$, ini berarti koefisien korelasi tersebut signifikan. Dengan demikian, hipotesis diterima, ada hubungan antara pengetahuan tentang sumber daya air dengan perilaku dalam memanfaatkan air. Artinya, semakin tinggi pengetahuan masyarakat tentang sumber daya air, maka semakin baik perilakunya dalam memanfaatkan air atau semakin efisen dalam pengunaan air.

\section{Hubungan Sikap Terhadap Penggunaan air dengan Perilaku dalam Memanfaatkan Air}

Hipotesis kedua yang diajukan dalam penelitian ini menyatakan ada hubungan antara sikap terhadap penggunaan air dengan perilaku dalam memanfaatkan air. Dari hasil analisis regresi linier sederhana terhadap data penelitian dihasilkan konstanta a sebesar 47,147 dan koefisien arah regresi b sebesar 0,374 . Bentuk hubungan antara kedua variabel dapat disajikan oleh persamaan regresi $Y=47,147+0,374$ $\mathrm{X}_{2}$.

Tabel 4.8

Rangkuman Analisis Regresi Hubungan Sikap terhadap Penggunaan Air $\left(\mathrm{X}_{2}\right)$ dengan Perilaku dalam Memanfaatkan Air $(\mathrm{Y})$

\begin{tabular}{lccccc}
\hline Sumber & JK & db & RK & F & Sig. \\
\hline Regresi & 1691.140 & 1 & 1691.140 & 10.765 & 0,002 \\
Residu & 9111.260 & 58 & 157.091 & & \\
\hline Total & 10802.400 & 59 & & & \\
\hline
\end{tabular}

Korelasi r $\quad=0,396$

Koefisien Determinasi $\left(r^{2}\right)=0,157$ 
Kekuatan hubungan antara sikap terhadap penggunaan air $\left(\mathrm{X}_{2}\right)$ dengan perilaku dalam memanfaatkan air $(\mathrm{Y})$ pada model persamaan $\mathrm{Y}=$ $47,147+0,374 \mathrm{X}_{2}$ dapat dilihat pada koefisien determinasi $\left(\mathrm{r}^{2}\right)$ adalah 0,157 . Ini berarti sikap terhadap penggunaan air kontribusi sebesar $15,7 \%$ terhadap perilaku dalam memanfaatkan air, sisanya dipengaruhi oleh variabel lain di antaranya pengetahuan tentang sumber daya air dan kebiasaan turun temurun warga.

Analisis korelasi terhadap pasangan data dari kedua variabel tersebut menghasilkan koefisien korelasi $\mathrm{r}$ sebesar 0,396 , artinya hubungan antar kedua variabel tersebut berada dalam kategori rendah. Keberartian koefisien korelasi tersebut selanjutnya diuji dengan menggunakan uji $t$ menghasilkan $\mathrm{t}_{\text {hitung }}$ sebesar 6,76 . dengan $\mathrm{db}=34$ pada taraf signifikansi $5 \%$ sebesar 4,96 . Ternyata $\mathrm{t}_{\text {hitung }}$ lebih besar dari $t_{\text {tabel }}$, ini berarti koefisien korelasi tersebut signifikan. Dengan demikian, hipotesis diterima, ada hubungan antara sikap terhadap penggunaan air dengan perilaku dalam memanfaatkan air. Artinya, semakin positif sikap masyarakat terhadap sumber daya air, maka semakin baik pula perilakunya dalam memanfaatkan air.

Hubungan Pengetahuan Tentang Sumber Daya Air dan Sikap Terhadap Penggunaan Air dengan Perilaku dalam Memanfaatkan Air

Hipotesis ketiga yang diajukan dalam penelitian ini menyatakan ada hubungan antara pengetahuan masyarakat tentang sumber daya air dan sikap masyarakat terhadap penggunaan air dengan perilaku dalam memanfaatkan air.
Dari hasil analisis regresi linier sederhana terhadap data penelitian dihasilkan konstanta a sebesar 43,775 dan koefisien arah regresi $b_{1}$ sebesar 0,699 dan koefisien arah $b_{2}$ sebesar 0,218. Bentuk hubungan antara ketiga variabel dapat disajikan oleh persamaan regresi $Y=43,775+0,699 X_{1}+0,218 X_{2}$.

Kekuatan hubungan antara hubungan pengetahuan tentang sumber daya air dan sikap terhadap penggunaan air dengan perilaku dalam memanfaatkan air pada model persamaan $\mathrm{Y}=43,775$ $+0,699 X_{1}+0,218 X_{2}$. dapat dilihat pada koefisien determinasi $\left(\mathrm{r}^{2}\right)$ adalah 0,206 . Ini berarti pengetahuan tentang sumber daya air dan sikap terhadap penggunaan air memberikan kontribusi sebesar 20,6\% terhadap perilaku dalam memanfaatkan air, sisanya dipengaruhi oleh variabel lain misalnya, tingkat pendidikan masyarakat, tingkat penghasilan, dan status sosial.

Analisis korelasi terhadap pasangan data dari ketiga variabel tersebut menghasilkan koefisien korelasi $\mathrm{r}$ sebesar 0,454 , artinya hubungan antar ketiga variabel tersebut berada dalam kategori cukup. Keberartian koefisien korelasi tersebut selanjutnya diuji dengan menggunakan uji $\mathrm{t}$ menghasilkan $\mathrm{t}_{\text {hitung }}$ sebesar 6,206 dan $\mathrm{t}_{\text {tabel }}$ dengan $\mathrm{db}=57$ pada taraf signifikansi $5 \%$ sebesar 4,96 . Ternyata $t_{\text {hitung }}$ lebih besar dari $t_{\text {tabel }}$, ini berarti koefisien korelasi tersebut signifikan. Dengan demikian, hipotesis diterima, yaitu ada hubungan antara pengetahuan tentang sumber daya air dan sikap terhadap penggunaan air dengan perilaku dalam memanfaatkan air. Artinya, semakin baik pengetahuan masyarakat tentang sumber daya air dan semkin positif sikapnya, semakin baik pula perilakunya dalam memanfaatkan sumber daya air.

Tabel

Rangkuman Analisis Regresi Hubungan Pengetahuan tentang Sumber Daya Air $\left(\mathrm{X}_{1}\right)$ dan Sikap terhadap Penggunaan Air $\left(\mathrm{X}_{2}\right)$ dengan Perilaku dalam Memanfaatkan Air (Y)

\begin{tabular}{lccccc}
\hline Sumber & JK & Db & RK & F & Sig. \\
\hline Regresi & 2226.972 & 2 & 1113.486 & 7.401 & 0.001 \\
Residu & 8575.428 & 57 & 150.446 & & \\
\hline Total & 10802.400 & 59 & & & \\
\hline
\end{tabular}

Korelasi r $\quad=0,454$

Koefisien Determinasi $\left(r^{2}\right)=0,206$ 


\section{SIMPULANDAN SARAN}

Mengacu pada hasil pengujian hipotesis sebagaimana yang telah dikemukakan pada bab sebelumnya, maka dapat disimpulkan bahwa:

Ada hubungan antara pengetahuan masyarakat tentang sumber daya air dengan perilaku dalam memanfaatkan air. Makin tinggi pengetahuan masyarakat tentang sumber daya air, makin positif pula perilakunya dalam memanfaatkan air. Hal ini ditunjukkan dengan $r=0,415$ dan $r^{2}=0,172$ artinya pengetahuan masyarakat tentang sumber daya air memberikan kontribusi sebesar $17,2 \%$ dan sisanya dipengaruhi olef faktor-faktor lain, seperti tingkat pendidikan dan tingkat pendapatan.

Ada hubungan positif antara sikap terhadap penggunaan air dengan perilaku dalam memanfaatkan air di Desa Linggasirna Kecamatan Sariwangi Kabupaten Tasikmalaya. Makin positif sikap masyarakat terhadap penggunaan air, makin positif pula perilakunya dalam memanfaatkan air. Hal ini ditunjukkan dengan $r=0,396$ dan $r^{2}=0,157$ artinya sikap masyarakat terhadap sumber daya air memberikan kontribusi sebesar $15,7 \%$ dan sisanya dipengaruhi olef faktor-faktor lain, seperti pengetahuan dan kebiasan turun temurun warga dalam memanfaatkan air.

Ada hubungan antara pengetahuan masyarakat tentang sumber daya air dan sikap masyarakat terhadap penggunaan air dengan perilaku dalam memanfaatkan air. Makin tinggi pengetahuan masyarakat tentang sumber daya air dan makin positif sikapnya terhadap penggunaan air, makin baik pula perilakunya dalam memanfaatkan air. Hal ini ditunjukkan dengan $r=0,454$ dan $r^{2}=0,206$, artinya pengetahuan masyarakat tentang sumber daya air dan sikap masyarakat terhadap sumber daya air memberikan kontribusi sebesar 20,6\% dan sisanya dipengaruhi olef faktor-faktor lain, seperti tingkat pendidikan, tingkat pendapatan dan status sosial.

Berdasarkan pembahasan dan kesimpulan sebelumnya, di bawah ini diajukan saran-saran sebagai berikut :

Pertama, kepada para peneliti yang menekuni bidang lingkungan hidup khususnya di bidang sumber daya air, sebagai studi lanjutan dari penelitian ini bisa dipelajari bagaimana hubungan berbagai variabel yang mempengaruhi perilaku sehingga didapatkan gambaran yang utuh mengenai perilaku tersebut serta faktor-faktor yang mempengaruhinya.

Kedua, pemerintah harus selalu berusaha melibatkan seluruh masyarakat dalam pemanfaatan sumber daya air untuk menghindari berkurangnya sumber-sumber air atau bahkan terlalu berlimpahnya air tetapi tidak dapat dikendalikan. Cara yang dapat ditempuh salah satunya adalah meningkatkan pengetahuan masyarakat tentang sumber daya air dan bahaya yang dapat ditimbulkan jika sumber daya tersbut berkurang atau bahkan hilang.

Ketiga, pemerintah terkait harus merancang dan membuat peraturan tentang pemanfaatan dan pengelolaan air serta mengawasi pelaksanaan peraturan tersebut di lapangan.

\section{DAFTARPUSTAKA}

Amsyari, Fuad. 1996. Membangun Lingkungan Sehat: Menyambur 50 tahun Indonesia Merdeka. Jakarta : Airlangga University Press

Djajadiningrat, surna T dan Harry Harsono Amir. 1998. Penilaian Secara Cepat Sumber-sumber Pencemaran Air, Tanah, dan Udara. Yogyakarta : Gadjah Mada University Press.

Doda, Johosua. 1989. Pendidikan Kependudukan dan Lingkungan Hidup. Jakarta : Dirjen Dikti Depdiknas

Entjang, Indan. 2000. Ilmu Kesehatan Masyarakat. Bandung : PT Citra Aditya Bhakti

Kusnanto, Hari (ed). 2001. Planet Kita Kesehatan Kita, : Laporan Komisi WHO Mengenai Kesehatan dan Lingkungan. Yogyakarta : Gadjah Mada University Press,

Notoatmodjo, Soekidjo. 1997. IImu Kesehatan Masyarakat. Jakarta : Rineka Cipta

Riyadi,Slamet. Ecology : Ilmu Lingkungan, Dasardasar dan Pengertiannya : Surabaya : Usaha Nasional.

Ritonga, Abdurrahman (ed).2001. Kependudukan dan Lingkungan Hidup. Jakarta : Lembaga Penerbit FEUI

Salim, Emil. 1996. Membangun Tanpa Merusak Lingkungan. Jakarta : Kantor Menteri Negara Kependudukan dan Lingkungan Hidup RI

Sudiarsa, I Wayan. 2004. Air Untuk Masa Depan. Jakarta : Rineka Cipta

Suriawiria, Unus. 2005. Air Dalam Kehidupan dan Lingkungan yang Sehat. Bandung : Alumni. 